\title{
Farmer involvement in agro-ecological research: organic on-farm wheat variety trials in Hungary and the Slovakian upland
}

\author{
Mihály Földi • Szilvia Bencze • Péter Hertelendy • Sára \\ Veszter • Tina Kovács • Dóra Drexler
}

Received: 5 May 2020 / Accepted: 13 November 2020

(C) Springer Nature B.V. 2021

\begin{abstract}
The acreage of organic farming is constantly increasing in Hungary. The cultivation of cereals - and within it - the production of winter wheat is of main importance in organic field crop production. Besides the challenges of global climate change, various difficulties are known, such as the inadequate variety assortment, lack of knowledge on the performance of varieties under organic conditions and often low quality of the seeds sown. As official post-registration variety trials only exist under conventional farming conditions in Hungary, the Hungarian Research Institute of Organic Agriculture (ÖMKi) started participatory organic on-farm variety tests in 2012, with the involvement of volunteer farmers all over the country. Over the past 7 years, nearly 60 wheat varieties and more than 20 farms have been included in the tests. The aim of the study was to find the most suitable varieties for high-quality organic wheat production and exclude inappropriate varieties for respective production regions. Results demonstrated that there is great potential in choosing varieties best suited to regional environmental conditions and that it is possible to achieve both high yield and excellent quality also in organic farming when adopting the appropriate varieties. The use of varieties, which were proven to be disease tolerant or resistant, can significantly contribute to safer organic production. The comparisons between
\end{abstract}

M. Földi · S. Bencze $(\bowtie) \cdot$ P. Hertelendy $\cdot$ S. Veszter •

T. Kovács · D. Drexler

ÖMKi, Hungarian Research Institute of Organic Agriculture,

Budapest, Hungary

e-mail: szilvia.bencze@biokutatas.hu the performance of varieties indicated that organic breeding has a great role in all of the above matters.

Keywords Organic farming · On-farm · Organic variety tests $\cdot$ Participatory research $\cdot$ Winter wheat

\section{Introduction}

Organic farming is widely acknowledged as a more sustainable alternative of food production than conventional cultivation systems (Lammerts van Bueren et al. 1999). In the absence of chemical pesticides and with the application of soil preserving techniques and a wider variety of plants grown on farms, organic farming practices lead to increased soil quality and enriched overall biodiversity whilst also avoiding environment pollution from synthetic fertilizers, herbicides or pesticides. Organic agriculture may result in a three times higher animal species diversity (including an increase in the rate of insects, arachnids and birds, Lu et al. 2020) and a $95 \%$ higher rate of plant species diversity (SteinBachinger et al. 2020). Moreover, the quality of organically farmed products may outperform those produced from conventional farming (Brandt et al. 2011, Mie et al. 2017).

On the other hand, for the same reason, i.e. because the use of artificial fertilizers and chemical pesticides is prohibited, the production of small-grain cereals is a major challenge in organic farming (Le Campion et al. 2020). Biological bases - choosing the most suitable variety - are of outstanding importance (Lammerts van 
Bueren et al. 1999). Production experiences from conventional farming are difficult to adapt to organic conditions (Murphy et al. 2007) due to the contrasting approaches of the two growing systems; the same variety is very unlikely to thrive equally well under both cultivation systems (Carr et al., 2006, Crespo-Herrera and Ortiz 2015).

In Hungary, organic farming methods are increasingly adopted since the 1980s. Among the production of arable crops, cereal cultivation has the highest acreage also in organic agriculture. In 2018, 33,246 ha were sown with organic cereals, occupying around $16 \%$ of all organic area in Hungary (KSH Annual Agricultural Report 2019). Among small-grain cereals, wheat cultivation represented the highest acreage both in conventional and organic agriculture. This sector, however, is most vulnerable due to changing climatic conditions; arable crops are being exposed not only to climate extremes but also to combined water and nutrient deficiencies. Extreme events of 2010, with the highest mean annual amount of precipitation (996 mm), and of 2011, the driest recorded year of the century (with $420 \mathrm{~mm}$ average precipitation, $\mathrm{KSH}$ meteorological database, n.d.) shed light on inadequate variety assortment available for organic farmers and on a lack of information on variety performance (ÖMKi 2013). Until the near past, organic farmers did not have a choice but to use conventionally bred varieties, which, however, were designed for intensive farming systems with a dependence on artificial fertilizers and pesticides (Lammerts van Bueren et al. 1999). Unfortunately, official pre- and post-registration organic variety trials have both been missing in Hungary up till now. The above reasons led to the initiation of the participatory on-farm variety trials that were begun by ÖMKi in 2012. This type of experimental system has long been used (since the 1970s) in the USA for research purposes but has also been adopted by some European Institutes such as Louis Bolk in the Netherlands, Organic Research Centre in England, NORSOK in Norway and FIBL in Switzerland, Germany and Austria (e.g. SARE 2012, ÖMKi 2013). In Hungary, as in the aforementioned countries, these types of tests provide unique opportunities to combine scientific experimentation with practical application, and to obtain reliable information on the performance of a great number of varieties at organic market operations all over the country. Based on data obtained on cultivation, performance, weed suppression and disease resistance under various climatic and environmental conditions, better variety recommendations can be made with regard to local circumstances. The participatory approach offers another perspective where the special needs or preferences of farmers (e.g. cultivation of only national varieties) can also be taken into account. This can lead to a-on the whole-more diverse, locally more adapted and optimized variety usage.

With our investigations, our goal was to identify varieties with high grain quality, which are more productive than the ones the farmers usually grow so that both crop yield and profitability could be enhanced. With the data collected on diseases, their risk could be better assessed. Via identifying disease-resistant/tolerant varieties, especially with regard to those with low mycotoxin contamination, the overall performance of the organic wheat sector could be improved - not only the grain yield and quality but food safety can also be further increased.

\section{Materials and methods}

Timeframe and varieties used

In 2012, four conventional winter wheat (Triticum aestivum L.) varieties of two local breeding companies (Agricultural Institute CAR, Martonvásár and Cereal Research Non-Profit Co., Szeged, Hungary) were sown on five volunteer organic farms together with the varieties the farmers usually grew on each site. These initial test varieties did not prove to be suitable and have been replaced with new accessions in the following years, during which both the number of the varieties and that of the participating farms have increased gradually. Altogether, until 2019, more than 20 farms and 60 varieties have been involved in the organic on-farm experiments across Hungary. Certain varieties have been excluded during the trials due to their low yield, high disease susceptibility, poor weed suppression ability or weak quality traits, or the sowing seeds of some were no longer available, and therefore they could not be tested any further. In the autumn of 2019 the variety assortment available for farmers included 24 modern Hungarian conventional varieties (one from CR Szeged, 20 from AI CAR Martonvásár, 2 varieties from DE ATC Karcag and one breeder's variety); one old Hungarian variety (Bánkúti 1201), 2 conventional Slovakian varieties (from Istropol), 9 Austrian conventional varieties recommended for organic agriculture (including 4 varieties from 
Probstdorfer Saatzucht and 5 from Saatbau Linz) and 6 organically bred varieties (2 from Saatzucht Edelhof, Austria; and 3 varieties and one organic heterogeneous population from Dottenfelderhof, Germany).

Due to space limitations and the rather complex experimental set-up, only the main findings of the latest two completed (though very contrasting) years are summarized here. The varieties investigated in these crop years originated from local breeding centres in Hungary and from conventional and organic breeding companies of Austria and Germany. In 2017-2018, 9 sites and 19 varieties were included in the tests, which meant in average 8.8 varieties per site and 4.3 sites per each variety. In the crop year of 2018-2019, 7 on-farm test sites participated and 34 varieties were tested in total with an average of 2.5 sites for each variety and 12.9 varieties per site, which was unusually high compared with 2018. The relatively low number of repetitions by site was due to the fact that 14 varieties were sown in one location only, mainly in Tiszasziget (see below), where the farmer decided to test as many varieties as possible.

\section{Main on-farm test sites}

Six of the testing sites have taken part in the on-farm experiments for four- to six-year intervals between 2013 and 2019 (Table 1 and Picture 1). They are representative of various regions in Hungary. The large farm (over 300 ha) of Tornyiszentmiklós is located near the western border of Hungary in the proximity of the Alps, resulting in relatively higher precipitation rates. Not surprisingly, the Austrian varieties were more popular and successful in this location, where they were grown under low-fertility soil conditions (brown forest type, clay loam). The small farm (approx. 60 ha) of Nagydorog is also situated in the Transdanubian area, but in the middle of the country, nearby the river Danube, and is characterized by poor sandy loam soil (meadow type) with low water-holding capacity. The farm applies no-till farming methods. The preferred variety grown by the farmer is Bánkúti 1201-the famous old, high-quality Hungarian variety. The other long-term on-farm test sites are located in the Great Hungarian Plains, which occupies the majority (52\%) of Hungary; however, different locations belong to different geographical regions. They all have meadow soils, the physical type of which is basically clay loam, but they differ greatly in fertility. Hajdúböszörmény is located in the East side of Hungary, characterized by a mixture of soil types (chernozem, soloniec, clayey and sand-based soils). The on-farm trials in the small farm of around 70 ha were conducted on fields with medium-fertile clay loam soil. The locally preferred variety, KG Kunhalom, due to its past use and good level of adaptability, soon became the control variety in the tests. Another small farm (50 ha) in Füzesgyarmat is also located in East Hungary but more to the South. At this site, reduced till is applied and water supply is slightly better, but it is also more exposed to inland water. Bánkúti 1201 wheat and its mixtures were preferred by the farmer. Tiszaigar, situated more to the central part of the Plains, is in the vicinity of Lake Tisza (Kisköre reservoir). On the medium-fertile soils of this large farm (above $1000 \mathrm{ha}$ ), Austrian wheat varieties are generally favoured. Tiszasziget can be found in the very South of the Plains near the city Szeged. The main profile of the middle-sized farm is vegetable production, as it has one of the most fertile soils in the country. Wheat production is relatively recent as it is only produced owing to crop rotation rules, and at this site, wheat varieties must be lodging resistant. The rest of the sites in Table 1 were involved in wheat trials on one occasion; thus their characteristics will not be detailed here. Želiezovce (Upland, Slovakia) is the only exception, for which the first testing year was 2018-2019; however, the collaboration has been continued since then. The farm is very close to the northern Hungarian border and is a good example for organic farming as it is a diversified, successful family enterprise with various production branches. Soil conditions (clay loam) have been greatly enhanced in the past 30 years, due to the soil and water preserving organic agricultural practices and the regular use of manure produced at the farm.

\section{Data collection and analysis}

One feature of the participatory on-farm experimentation is that not all of the varieties are sown in all locations but most varieties are grown in at least three experimental sites based on the farmers' choice and preferences. To allow comparisons between sites, a control variety (KG Kunhalom) was used in all testing sites. Some variation in participating farms was also expected; however a 'core' group of farmers took part in the trials for several subsequent years. For each farm, the variety assortment was chosen based on the farmer's demand, e.g. how many varieties and what type they 
Table 1 Testing sites in the last 2 years (2017-2018 and 2018-2019)

\begin{tabular}{llll}
\hline Name of site & Successful testing years (harvest years) & Precrop in 2016-2017 & Precrop in 2017-2018 \\
\hline Tornyiszentmiklós & $2014,2015,2016,2017,2018,2019$ & Oat & Soybean \\
Nagydorog & $2014,2015,2016,2017,2018,2019$ & Millet & Corn and squash \\
Hajdúböszörmény & $2014,2015,2016,2017,2018,2019$ & Sunflower & Sunflower \\
Füzesgyarmat & $2013,2016,2017,2018,2019$ & Mustard & Millet, mustard and fallow \\
Tiszasziget & $2016,2017,2018,2019$ & Fallow & Potato \\
Tiszaigar & $2015,2017,2018,2019$ & Sunflower & Sunflower \\
Pásztó & 2018 & Fallow & Not tested \\
Nagykáta & 2018 & Alfalfa & Not tested \\
Nyírtelek & 2018 & Triticale & Not tested \\
Želiezovce & 2019 & Not tested & Sunflower
\end{tabular}

intended to grow. Sowing seeds (typically $30-50 \mathrm{~kg}$ of each variety) were provided for farmers who were requested to sow them in strips (usually in the width of their sowing machine), side by side, in a fairly homogenous part of their field. From the autumn of 2018, the control variety was sown in two replicates in each experiment, in order to estimate field heterogeneity effects. The agricultural practices applied in each farm were rather specific and corresponded to the usual routine of the farmer.

During field surveys, data on the incidence and severity of relevant diseases and pests were recorded for each variety at each site, together with the actual phenological stage of the plants, which was documented according to the $\mathrm{BBCH}$ growth scale. Diseases were usually assessed during May-June and reported as the

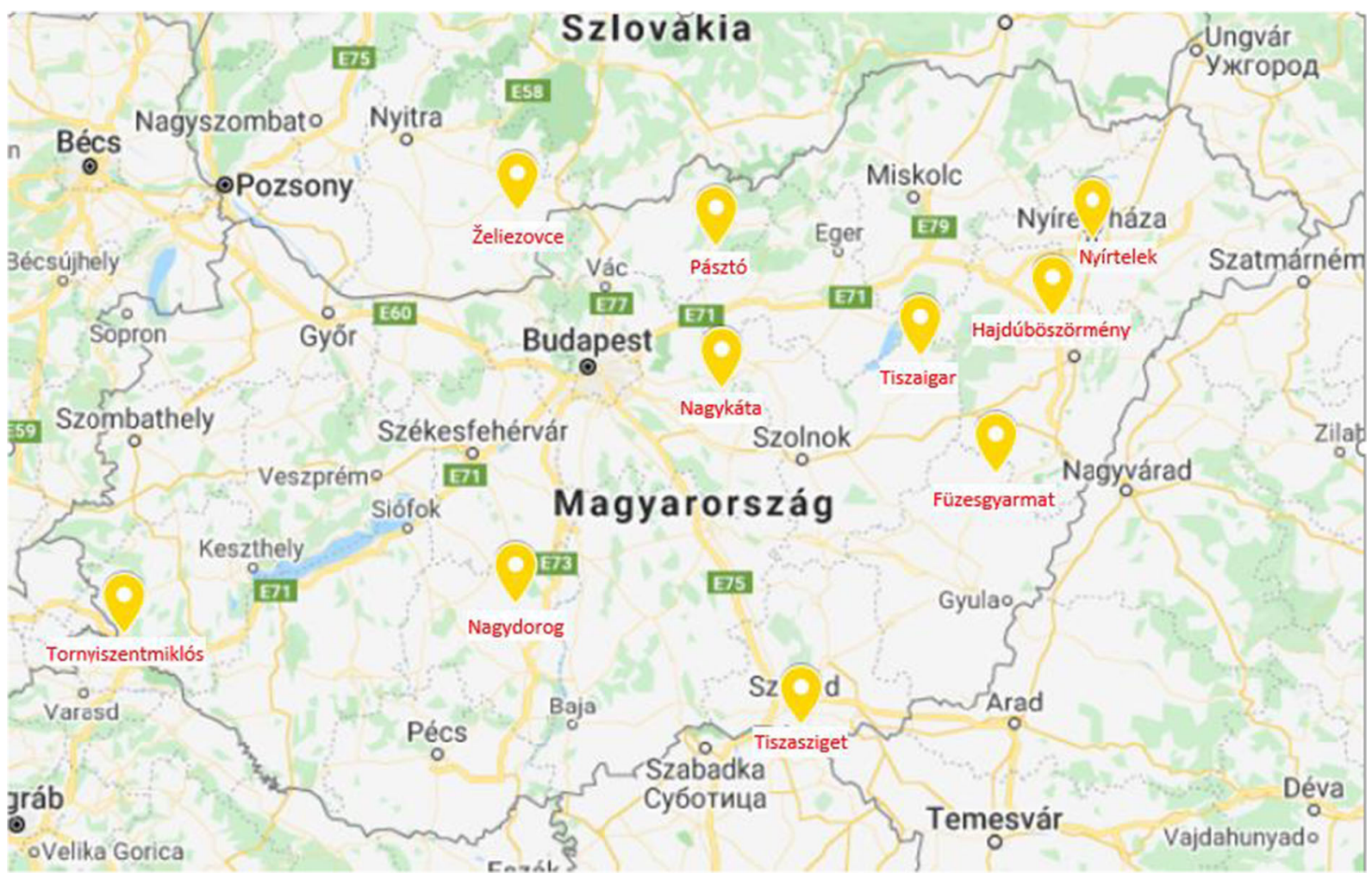

Picture 1 Location of on-farm test sites of 2017-2018 and 2018-2019 in Hungary and Slovakia 
percentage of plants (or spikes in the case of Fusarium head blight-FHB) infected (i.e. incidence) and the percentage of leaves on plants showing disease symptoms or for FHB, spike surfaces infected (severity). Grain infection rate was calculated as the percentage of the seeds exhibiting symptoms of Fusarium infection in three subsamples of the harvested yield. As the locations were far from each other, due to travelling constraints field surveys were performed at around anthesis and before harvest.

Yield was determined after full maturity, via collecting the spikes with a sickle from $3 \times 1 \mathrm{~m}^{2}$ representative squares. The spikes were threshed with Wintersteiger LD 350 laboratory thresher, and the obtained grain samples were measured with a NIR equipment (Mininfra Scan-T Plus, Infracont) for grain quality traits. The results were related to the generally used Hungarian quality standards (MSZ 6383 2017). Deoxynivalenol (DON) content was determined according to the VICAM DON test protocol for HPLC (VICAM DonTest GN-MC9560-1 Rev.B, online). Zearalenone (F2) measurements were carried out according to the QM-M-F2-HPLC-2:2007 standard.

\section{Statistical analyses}

According to the original, rather complex experimental design (i.e. not the same group of varieties were cultivated in all of the sites and years), the design corresponded to and incomplete block design. Statistical analysis of the data was carried out with mixed models and Bayesian models. Several mixed models were examined. The selection of the 'best' model was based on the Akaike Information Criterion (AIC) as well as that on the Bayesian Information Criterion (BIC).

With a Bayesian analysis, research questions about unknown parameters of statistical models could be answered by using probability statements. Bayesian analysis rested on the assumption that all model parameters were random quantities that can incorporate prior knowledge. Bayesian analysis followed the Bayes rule to combine prior information with evidence from the data and resulted in presenting the posterior distribution of model parameters. All statistical tests about model parameters could be expressed as probability statements based on the estimated posterior distribution.

For a nested Bayesian model for both zyield (yield zscore) and zprotein (protein z-score), mcmcsize was set to 20,000 , burnin was 5000 , number of dots was 500 and thinning was 6. Gibbs sampling was used for variance components discarding every 5 sample observations. Within the nested model the parameter, $\{\mathrm{U} 0\}$ represented a random intercept for year, $\{\mathrm{UU} 0\}$ represented that for site, and $\{U U U 0\}$ represented that for variety concerning both zyield and zprotein. The parameters \{e.zyield:sigma2\} and \{e.zprotein:sigma2\} referred to the error variance. Prior distribution for the probability of zyield and zprotein, respectively, was a slightly informative normal $(0,\{\mathrm{U} 0: \operatorname{sigma} 2\})$, normal( $0,\{\mathrm{UU} 0$ :sigma 2$\})$ and normal $(0,\{\mathrm{UUU} 0$ :sigma 2$\})$ distribution for year, site and variety, respectively. The variance components for year, site and variety $\{\mathrm{U} 0:$ sigma2, UU0:sigma2, UUU0:sigma2\} were assigned the default inversegamma prior with 0.01 for both the shape and scale parameters (Garson 2020; Hoaglin et al. 1991; Hox 2010; Mitchell 2015; Robson and Pevalin 2016).

Stata Statistical Software: Release 16 was used for the calculations (StataCorp. 2019).

\section{Results}

\section{General findings}

Based on both the mixed linear model and the Bayesian model, it was found that the standardized yield (zyield) as well as the standardized protein content (zprotein) significantly differed in decreasing order by year, site and variety, respectively, due to random effects, i.e. the 'crop year' had the greatest effect, while the 'site' had a medium impact and the 'variety' had the lowest influence on the variability of grain yield and protein content. In other words, the components of variance were year, site, variety and error in decreasing order. The harvesting year of 2018 exhibited significantly lower yields than 2019. From the test sites, Tiszasziget and Želiezovce were the highest producing locations, while the lowest yields were obtained in Pásztó, Nyírtelek, Nagydorog and Nagykáta. Regarding the varieties, the difference between years was so big that it affected the ranking of the varieties greatly.

Crop year characteristics of 2017-2018

In 2018, organic wheat cultivation was severely influenced by the extreme spring drought (Hungarian Meteorological Service 2018), which resulted in generally low yield values (Fig. 1). Infections of leaf fungal 
diseases, such as Septoria tritici, leaf and yellow rusts were present; however, only Septoria and leaf rust incidences were more significant (causing moderate infections) in some locations. Differences between sites were great as the average grain yield varied between 1.5 and $4.2 \mathrm{t} / \mathrm{ha}$, with the mean value of $2.5 \mathrm{t} / \mathrm{ha}$. Taking into account only varieties which were grown in at least three locations, the varietal differences were also considerable; the grain yield averaged over the sites varied between 1.9 and $3.0 \mathrm{t} / \mathrm{ha}$. With its mean yield of $2.7 \mathrm{t} /$ ha (on 9 sites), the control variety, KG Kunhalom apparently adapted well to poorer and moderate environments and also performed acceptably in farms with the best conditions. In Tiszasziget, however, where soil conditions are outstanding and the highest yields are usually obtained, top conventional varieties (e.g. Mv Nádor) had the highest yield and best quality results (Fig. 1). Besides KG Kunhalom, Lukullus, Capo and Adesso produced higher yields under moderately good growing conditions. The more modestly yielding old Hungarian variety, Bánkúti 1201 had, however, high quality under all conditions, including poor soil characteristics, which might explain why it is still appreciated so much by Hungarian organic farmers. Though yield was lower, quality was basically higher in 2018 compared to the previous season (data not shown here). In some locations, however, both the quantity and the quality of the grain were low; while at other sites, quality traits were rather variable, and did not seem to be closely associated with the grain yield.

\section{Crop year characteristics of 2018-2019}

Despite the fact that the extreme drought of 2018 continued in the autumn, greatly hindering sowing and emergence for the next crop year, 2019 could be considered after all as a wet year for wheat due to the extraordinary May precipitation rate (218\% of the 30year average, Hungarian Meteorological Service 2019). This also had implications on the disease rates (detailed below).

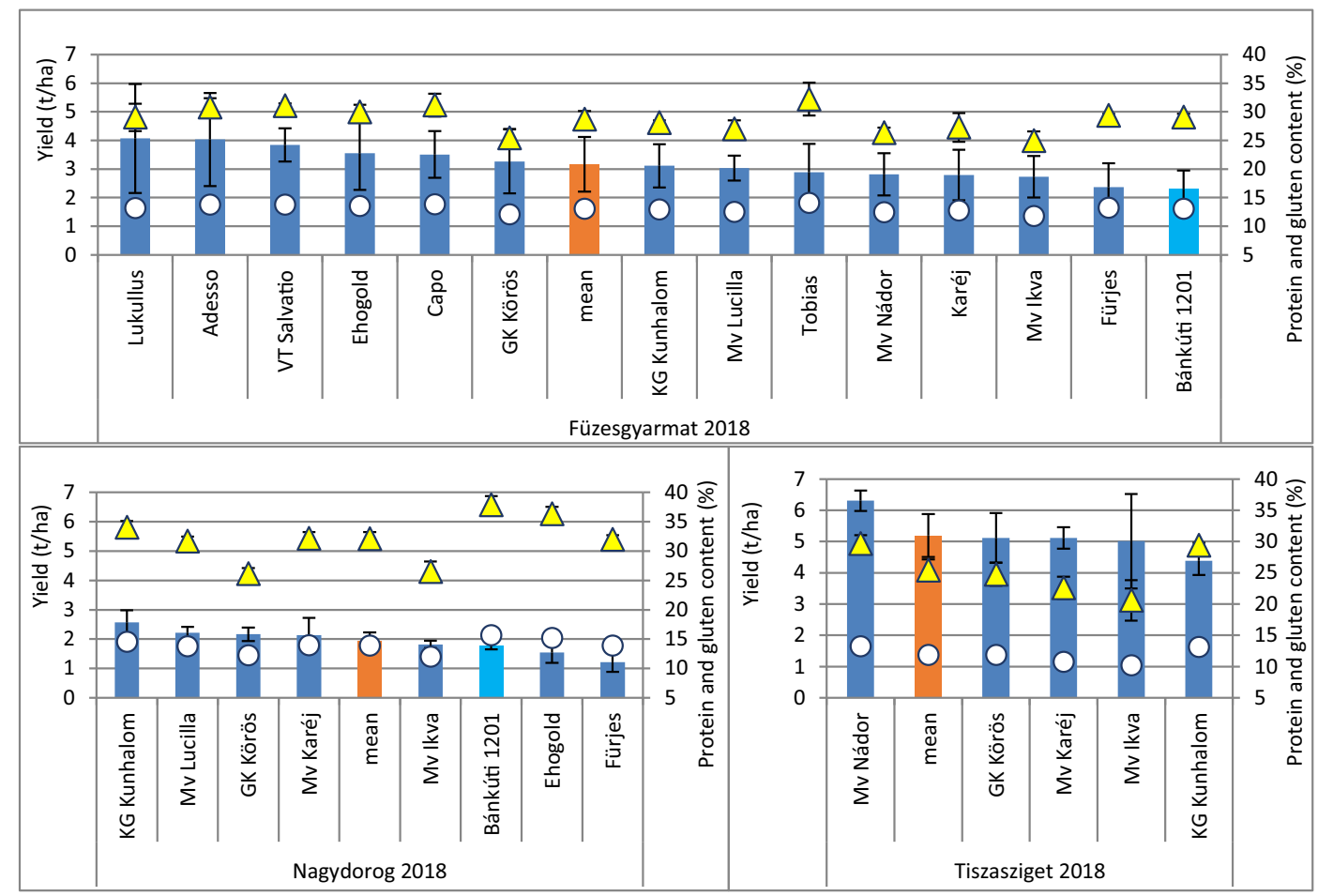

Fig. 1 Grain yield and quality at three typical test sites of 2018. Columns, dots and triangles refer to the average grain yield (left axis), protein and gluten content (right axis), respectively. Mean values are indicated with red, while the farmer's preferred variety is shown with light blue. Grain quality levels are classified as milling II, milling I, and premium quality with reference minimum values of $11.5,12.5$ and $14 \%$ for protein and 26,30 and $34 \%$ for gluten content, respectively, according to the Hungarian MSZ 63832017 standard. Values lower than those given above indicate feed quality. Standard deviation bars are presented for all the parameters 
The average grain yield (over sites) was relatively high, 4.9 t/ha (compared to 2018), varying between 2.8 and $6.8 \mathrm{t} / \mathrm{ha}$. The top three ranking sites were Tiszaigar, Želiezovce (Slovakia) and Tiszasziget, which not only had the highest grain yields but also the highest protein and wet gluten values; performing 6.8, 6.1, 5.0 t/ha yield, 14.8, 14.7, 15.0\% protein content and 31.8, $31.6,31.5 \%$ wet gluten content, respectively. Some varieties even had $7 \mathrm{t} / \mathrm{ha}$ yields and more. In some of the test sites where the soil conditions were more limiting, e.g. in Nagydorog, there was a variation in the quality but not in the grain yield (no significant differences could be detected). However, compared with 2018 , the quality parameters were higher in general (Fig. 2).

In this wet year, the best performing varieties in general were the Austrian varieties either recommended or bred for organic agriculture, such as e.g. Arnold, Tobias, Ehogold, Capo and Lukullus, together with some Hungarian varieties (Fürjes, Mv Kolo, Mv Kikelet) on certain locations with possibly more typical continental conditions for Hungary. This was not the best year of KG Kunhalom, the control variety; however, it had a good or medium performance.

Disease severity in 2019

Because of the extremely rainy May, 2019 was favourable for the spread of fungal diseases and was especially suitable for comparisons between various accessions with different Fusarium susceptibility. From the leaf diseases, however, powdery mildew was of minor importance and also leaf rust could be detected at only three locations in insignificant amounts. Drechslera tritici-repentis (DTR) and Septoria tritici caused higher rate of infections with medium severity (in Tiszaigar, Füzesgyarmat, Nagydorog and Želiezovce). There were great differences in the disease levels between the varieties but also in infection severity observations at different locations. This was also true for Fusarium, for which the example of Füzesgyarmat (with one of the strongest infection levels) shows that there were varieties which were infected to a lesser extent by this disease (Fig. 3). The DON determination carried out on 9 selected varieties grown at this site showed that certain varieties with low seed infection rates had low levels of DON mycotoxin, below the threshold limit $(1250 \mu \mathrm{g} / \mathrm{kg})$, or similar concentrations, such as Arnold (710), Bánkúti 1201 (703), KG Kunhalom (428-only on the fallow pre-crop site) and Capo $(1254 \mu \mathrm{g} / \mathrm{kg})$. While the rest of the tested varieties had 1504$2465 \mu \mathrm{g} / \mathrm{kg}$ and one had $4088 \mu \mathrm{g} / \mathrm{kg}$ DON content. However, no correlation was determined between seed infection rate and DON content in the more susceptible varieties. In these 9 samples, however, no Zearalenone contamination was confirmed as the detection limit for ZEA measurement was not exceeded in any of the examined cases.

\section{Model selection}

Among the several mixed models fitted for yield and protein content, the smallest AIC and BIC values (672.4 and 693.7, respectively) were found where year, site and variety were all random effects indicating that these were the best models (Table 2). For mixed modelling standardized yield and protein content (zscores) and unstructured covariance matrices were used with the restricted maximum likelihood (REML) approach (Table 3).

The parameters of this nested Bayesian model were similar to that of the previous traditional mixed model in that the standardized yield (zyield) and the standardized protein content (zprotein) significantly differed in decreasing order by year, site and variety within the Bayesian model (Table 4).

Some figures of the Bayesian analysis results for zyield (yield z-score) and zprotein (protein content zsore) are relegated to the appendix.

\section{Discussion}

General findings, crop year effect, varieties - 2018 vs. 2019

Organic breeding has a great potential - this was one of our main findings confirmed by our 7-year on-farm tests as for most varieties from conventional farming organic cultivation was a major challenge. This is in accordance with previous findings (Carr et al., 2006, Lammerts van Bueren et al. 1999, Murphy et al. 2007, Crespo-Herrera and Ortiz 2015, Le Campion et al. 2020). Our results also shed light on the great role of organic variety testing in Hungary. Some Austrian varieties, which are recommended for or bred under organic farming conditions, performed, however, well on several locations of 


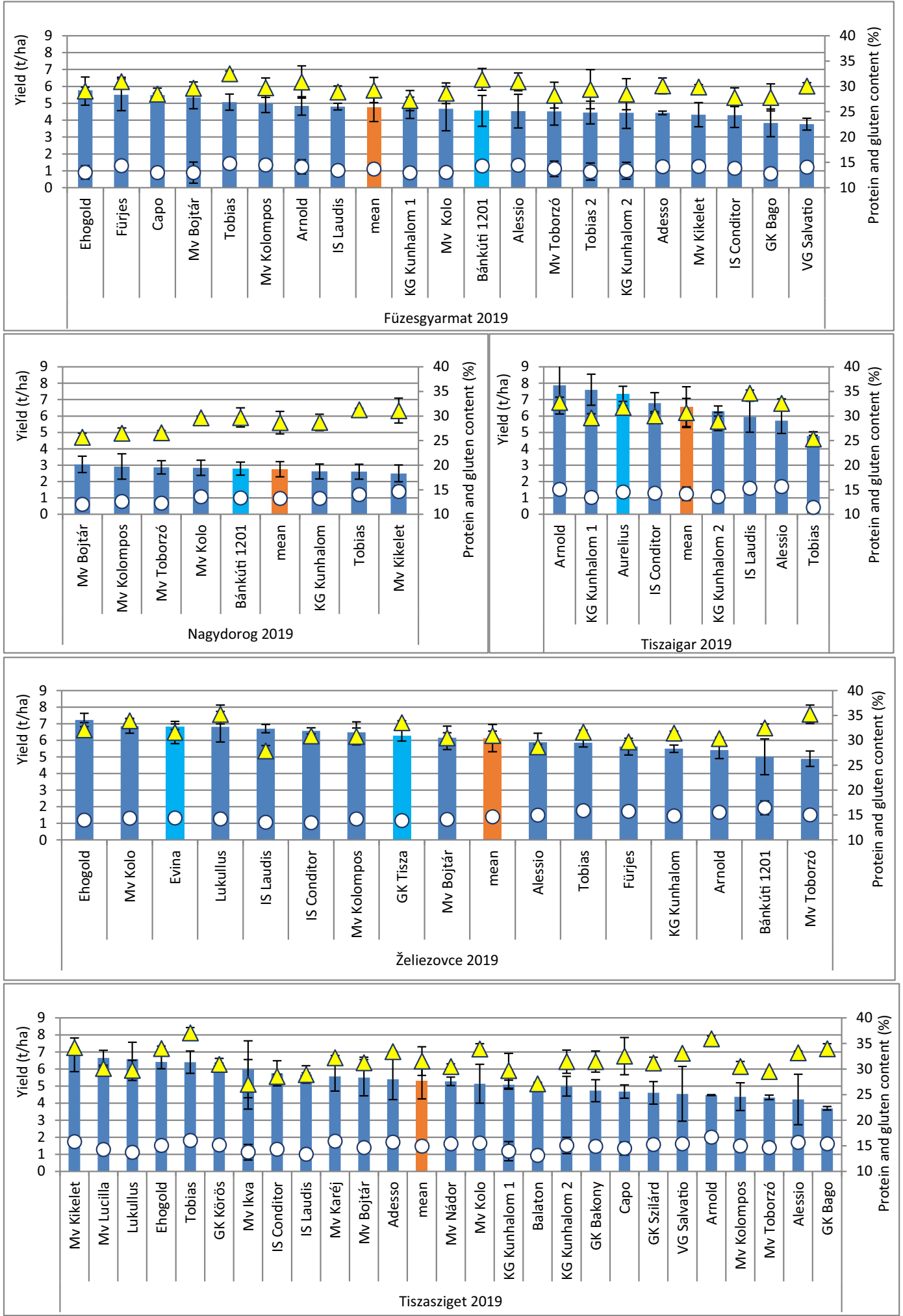

Fig. 2 Grain yield and quality at five test sites of 2019. The columns refer to the grain yield, the dots to the protein and the triangles to the gluten content of the grains. (For further explanations see Fig. 1) 


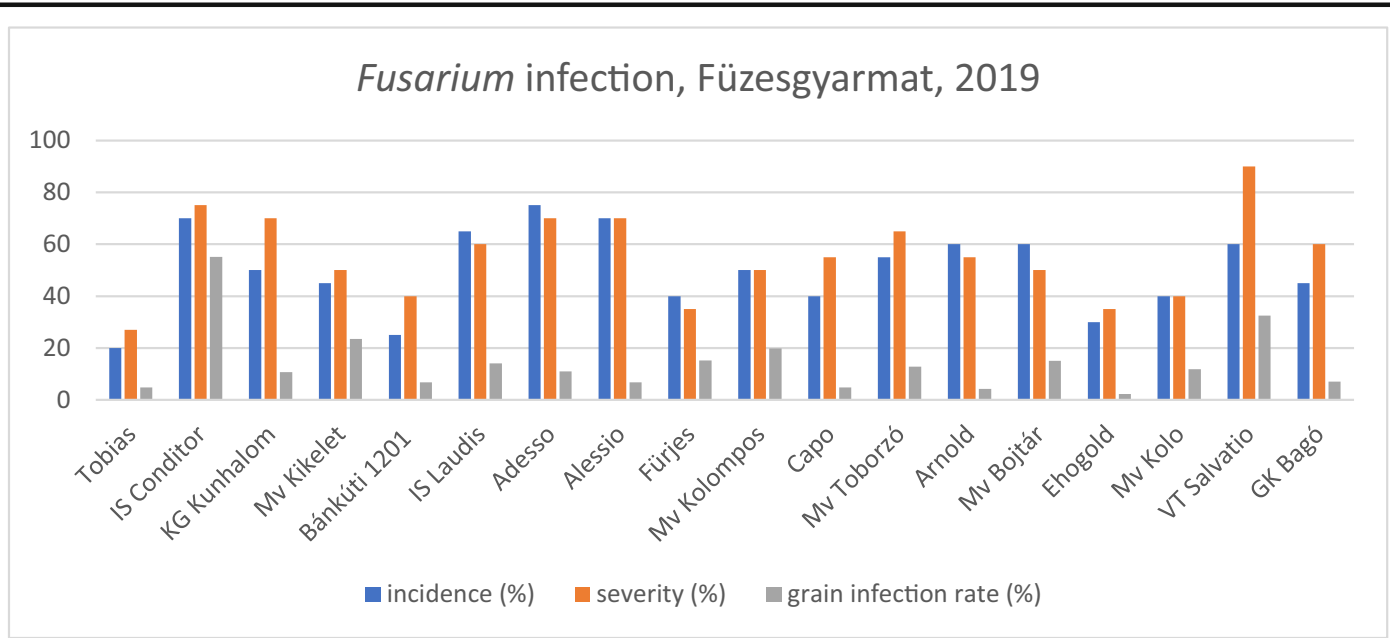

Fig. 3 Fusarium infection rate in Füzesgyarmat shown by variety. Percentage of the infected spikes (incidence), proportion of infection on the surface of infected spikes (severity), and the grain infection rate are shown

Hungary. We found that in the wet year of 2019, these varieties were among the top varieties on most locations, and, at some sites, they also performed well in the dry year of 2018. This may be explained by the fact that these accessions were bred under a more Atlantic Western climate and are less adapted to the frequently more extensive Hungarian environments. Under dry conditions, the Hungarian varieties were better positioned, proving their tolerance to the more continental climate of Hungary. The control Hungarian variety, KG Kunhalom, exhibited the widest adaptation ability with respect to both yield and quality. Mv Nádor, a highyielding conventional variety, which has the highest acreage in Hungary, was also productive at the site with the best soil conditions (Tiszasziget). The biggest difficulty with conventional varieties, however, was their poor weed suppression ability and low yield stability.
These varieties did not produce as well under more extensive environments, arid or marginal conditions. Prominent examples for the former problem were the Martonvásár varieties, which, being short-strawed, with high harvest index, were usually not able to control the overgrowing weeds, which in some cases even reached $60-80 \%$ coverage on the soil surface (previous observations, data not shown here). Wheat varieties bred or recommended for organic production did not exhibit these problems.

Soil condition is also identified as a limiting factor on many Hungarian locations (European Soil Data Centre (ESDAC) database, n.d.), which affects a considerable proportion of the organic lands. Heterogeneity of the environment is also problematic but the adaptation ability of the varieties can, however, be improved by modern organic breeding (Desclaux et al. 2012). Modern

Table 2 Model selection with Akaike and BIC Information Criterion (AIC, BIC); for both AIC and BIC smaller value was better

\begin{tabular}{|c|c|c|c|c|}
\hline \multirow[b]{2}{*}{ Mixed model } & \multicolumn{2}{|c|}{ zyield (z-score of yield) } & \multicolumn{2}{|c|}{ zprotein (z-score of protein content) } \\
\hline & AIC & $\mathrm{BIC}$ & AIC & $\mathrm{BIC}$ \\
\hline SITE random & 1082.1 & 1094.9 & 1092.0 & 1104.7 \\
\hline VARIETY random & 1410.1 & 1422.9 & 1422.3 & 1435.1 \\
\hline YEAR fixed, when SITE random & 866.4 & 883.4 & 1029.2 & 1046.3 \\
\hline YEAR fixed, VARIETY random & 1097.8 & 1114.8 & 1275.2 & 1292.3 \\
\hline YEAR and VARIETY fixed, SITE random & 877.8 & 899.1 & 1033.5 & 1054.8 \\
\hline YEAR fixed, SITE and VARIETY random & 774.0 & 795.3 & 935.5 & 956.8 \\
\hline YEAR, SITE and VARIETY random & 672.4 & 693.7 & 795.6 & 816.9 \\
\hline
\end{tabular}


Table 3 Parameters of mixed effect model where all effects were considered as random (zyield: yield z-score, Coef: coefficient, Std Err.: Standard Error, z: z-value, $P<|z|$ : significance, LL 95\% CI: lower level confidence interval, UL 95\% CI: upper level confidence interval)

\begin{tabular}{|c|c|c|c|c|c|c|}
\hline zyield & Coef. & Std. Err. & z & $\mathrm{P}>|\mathrm{z}|$ & LL $95 \%$ CI & UL $95 \% \mathrm{CI}$ \\
\hline cons & -0.057 & 0.654 & -0.090 & 0.930 & -1.340 & 1.224 \\
\hline Random effects Parameters & Estimate & Std. Err. & LL $95 \%$ CI & UL 95 & & \\
\hline year: sd(_cons) & 0.896 & 0.675 & 0.204 & 3.930 & & \\
\hline site: sd(_cons) & 0.637 & 0.125 & 0.433 & 0.938 & & \\
\hline variety: sd(_cons) & 0.277 & 0.025 & 0.230 & 0.332 & & \\
\hline sd(Residual) & 0.367 & 0.013 & 0.341 & 0.395 & & \\
\hline \multicolumn{4}{|c|}{ LR test vs. linear model: $\operatorname{chi} 2(3)=816.68$} & \multicolumn{3}{|c|}{ Prob $>$ chi $2=0.0000$} \\
\hline zprotein & Coef. & Std. Err. & z & $\mathrm{P}>|\mathrm{z}|$ & LL $95 \%$ CI & UL $95 \% \mathrm{CI}$ \\
\hline _cons & -0.134 & 0.517 & -0.260 & 0.794 & -1.148 & 0.878 \\
\hline Random effects Parameters & Estimate & Std. Err. & LL $95 \% \mathrm{CI}$ & UL 95 & & \\
\hline year: sd(cons) & 0.688 & 0.550 & 0.143 & 3.299 & & \\
\hline site: sd(_cons) & 0.678 & 0.136 & 0.457 & 1.005 & & \\
\hline variety: sd(cons) & 0.432 & 0.030 & 0.375 & 0.497 & & \\
\hline sd(Residual) & 0.375 & 0.014 & 0.348 & 0.404 & & \\
\hline \multicolumn{4}{|c|}{ LR test vs. linear model: $\operatorname{chi} 2(3)=704.88$} & \multicolumn{3}{|c|}{ Prob $>$ chi $2=0.0000$} \\
\hline
\end{tabular}

conventional varieties tend to perform best under more providing conditions, while the old variety, Bánkúti 1201 was a good choice for nutrient deficient, dry soils (e.g. Nagydorog), where it yielded similar rates than other varieties but had good quality and low Fusarium infection levels. It is interesting to note that even this moderate-yielding old variety could produce around $5 \mathrm{t} /$ ha under favourable conditions.

In 2018 the average national wheat production rate in Hungary was $5.1 \mathrm{t} / \mathrm{ha}$, and $5.3 \mathrm{t} / \mathrm{ha}$ in 2019 . The 2.5 and $4.9 \mathrm{t} / \mathrm{ha}$ results presented in this study indicate the sensitivity of the organic sector to climate anomalies: extreme drought, often combined with nutrient shortage due to restricted water supply limiting nutrient uptake. However, results of the 2019 study year are impressively close to the national average. Although in 2019 three previously lowyielding sites dropped out of the study (because they either did not produce wheat or just did not go further with the tests), while the Želiezovce site (one of the highest producing farms) joined the study, these might also have influenced the average value. Nonetheless, three more locations out of the seven sites also yielded around $4.5 \mathrm{t} / \mathrm{ha}$ or more in 2019. The three best locations had varieties yielding above 7 t/ha while also having other relevant highquality traits. The high average values may have been partly due to high precipitation rates and favourable environmental conditions of the trial sites and also could be the result of the farmers' commitment to professional management and high-level organic farming practices.

It is possible to conclude that in most locations, better varieties could be identified than the farmers' generally preferred varieties, both in terms of crop yield and quality. Such own varieties were, e.g. Mulan and Aurelius in Tiszaigar, Albertus, and Arminius in Tornyiszentmiklós, KG Kunhalom in Hajdúböszörmény, GK Tisza and Evina in Želiezovce, and Bánkúti and its mixes in Füzesgyarmat. In Nagydorog, Bánkúti 1201 was identified as a good choice for the farmer (see above), and this variety was also found to be marketable as 'special quality flour' produced by the smallholder.

While in the first years of the on-farm trials, wheat varieties were either found to have high grain quality or high yield, after many years of tests and due to the improved variety assortment it was possible to confirm that there are alternative varieties available to farmers, which possess both high productivity and quality attributes. Finally, the relationship between grain yield and quality was found to be greatly influenced by the trial site, while stability, either of yield or quality, was found as a question of variety. As extreme weather events are becoming more and more 
Table 4 Parameters of Bayesian nested model (zyield: yield zscore, Coef: coefficient, Std Err.: Standard Error, z: z-value, $P<|z|$ : significance, LL 95\% CI: lower level confidence interval, UL 95\% CI: upper level confidence interval, MCSE: Monte-Carlo Standard
Error, U0: random intercept for year, UU0: random intercept for site, UUU0: random intercept for site and variety, e.zyield:sigma2: error variance concerning zyield (yield z-score) and zprotein (protein content z-score), respectively

\begin{tabular}{lllllll}
\hline Bayesian analysis & & & & & \multicolumn{2}{c}{ Equal-tailed 95\% credibility interval } \\
\cline { 3 - 6 } Posterior summary statistics & Mean & Std. Dev. & MCSE & Median & LL & UL \\
\hline zyield cons & -0.225 & 0.600 & 0.109 & -0.137 & -1.556 & 0.758 \\
year: U0:sigma2 & 6.187 & 84.255 & 0.595 & 0.877 & 0.069 & 30.620 \\
year>site: UU0:sigma2 & 0.478 & 0.219 & 0.004 & 0.430 & 0.211 & 1.027 \\
year>site>variety: UUU0:sigma2 & 0.077 & 0.014 & 0.000 & 0.076 & 0.051 & 0.108 \\
e.zyield sigma2 & 0.136 & 0.010 & 0.000 & 0.135 & 0.117 & 0.178 \\
Equal-tailed 95\% credibility interval & & & & & UL \\
Bayesian analysis & Mean & Std. Dev. & MCSE & Median & LL & 0.868 \\
zprotein cons & -0.196 & 0.594 & 0.099 & -0.124 & -1.798 & 20.815 \\
year: U0:sigma2 & 4.434 & 53.257 & 0.376 & 0.483 & 0.021 & 1.193 \\
year>site: UU0:sigma2 & 0.550 & 0.261 & 0.008 & 0.492 & 0.233 & 0.249 \\
year>site>variety: UUU0:sigma2 & 0.189 & 0.027 & 0.000 & 0.187 & 0.140 & 0.164 \\
e.zyield sigma2 & 0.142 & 0.010 & 0.000 & 0.141 & 0.122 & \\
\hline
\end{tabular}

frequent such knowledge on the varieties, i.e. their potential of adaptability and stress tolerance has great importance in the future.

Disease threat and variety resistance

Different crop years might favour different pathogens, in accordance with their requirements (Murray et al. 1998), which was also confirmed by our results, however, a variation in the resistance of the varieties to pathogens was detected. This was also true for Fusarium species, for which the humid year of 2019 resulted in a severe epidemic in Hungary (Csertán-Halász 2020). For this disease, different resistance types might be responsible for the observed variation in the infection incidence, severity and grain infection rates (Mesterházy 1995 and 2002, Buerstmayr et al. 2009). For example, in some varieties only a few spikes became infected (type I, penetration), while in others the spread was hindered in the rachis (type II), i.e. severity was less, or DON mycotoxin levels were low (Type III), or grain infection was moderate (type IV). Resistance against Fusarium is horizontal, meaning that existing resistance protects plants against various Fusarium species (Mesterházy 1977), while different Fusarium species (and pathotypes) have different virulence and toxin production rates (e.g. Bencze et al. 2017). Interestingly, the famous old Hungarian wheat variety bred at the beginning of the last century, Bánkúti 1201, which exhibits landrace-type characteristics (is a kind of mixture with genetic heterogeneity), still had low Fusarium infection rates on all locations. These findings were in accordance with previous investigations, finding this variety the most tolerant of all varieties studied (Szunics and Szunics 1992). Bánkúti 1201 was also found to possess very low DON content together with some modern varieties. While organic production may be criticized because of the lack of chemical pesticide use, varieties with affirmed low mycotoxin levels are encouraging and provide an opportunity to ensure high food safety standards. This finding is especially important, because in the trial period also conventional cultivation failed to control the disease, despite measures being taken to omit Fusarium, however, farmers were limited in their efforts due to continuous rainfall and soaked soil (Avar 2019).

For other diseases, even under conditions that favoured fungal pathogens, it was found that they had no or minor symptoms (e.g. powdery mildew) or moderate levels (DTR, Septoria) but with negligible effects on crop performance. Therefore, in contrast with some preconceptions, the general rate of wheat infections may be fairly low in organic farming because of more careful variety selection, crop rotation techniques applied for disease prevention, and due to the lower levels of some 
nutrients in organically farmed land compared with the conventional practice. Lower levels of $\mathrm{N}$ can restrain e.g. biotrophic fungi such as powdery mildew and rusts (Snoeijers et al. 2000, Dordas 2008). Thus, the present work noted significant differences in disease rates and also in the presence of pathogen organisms at different sites in the same study year. These findings were closely associated with environmental effects, which included the soil type, nutrient supply, applied agricultural practices at a farm, besides climatic disparities.

Our results demonstrated that disease resistant or tolerant varieties are available on the market providing farmers the possibility for safe organic wheat production. The relationship between DON contamination and other factors needs to be further clarified, such as e.g. a pre-crop effect proved by our preliminary results which demonstrated in the variety KG Kunhalom that DON concentration was much lower after fallow than in the case of millet or mustard (data not presented here).

\section{On-farm conclusions}

The on-farm variety trial system, with its participatory approach, presents the working example of an agroecological Living Laboratory methodology (ENoLL, n.d.), and as such targets the purposes and preferences of the farmers and their respective value chains. Findings illustrate the importance of local conditions, while the aim is to improve production on the farm level. This is not a 'classical' approach to scientific testing; our study tested only varieties that were more suitable, possibly more adapted to each farm, and did not follow-up on data illustrating results on inappropriate varieties. As farmers were found to decide using crops based on their performance in the previous year, they may be prone to choose varieties based on extraordinary years, rather than yield stability. On-farm tests may provide sufficient scientific data to ensure evidencebased recommendations on varieties for the farmer to choose from. Based on the 7 years of ongoing on-farm tests, we find that for most sites some varieties provided higher or more stable yields, or indeed presented higher quality attributes than the farmer's preferred variety both in 'good' and 'bad' years. The study has also demonstrated that there are very efficient examples of organic farming (e.g. the farm of Želiezovce), where not only grain quality but also grain yield can be outstanding. The results of on-farm trials are therefore promising, and the special features of such participatory tests can be used to demonstrate best-practices, thereby fostering the agro-ecological transition to more sustainable, environmentally friendly agricultural practices in Europe and beyond.

Supplementary Information The online version contains supplementary material available at https://doi.org/10.1007/s13165020-00335-x.

Acknowledgements The researchers of ÖMKi would like to thank all the participating farmers and partners for their work and support; to László Molnár for his assistance in the statistical analyses of the data; and to AI CAR Martonvásár, CR Szeged, DE ATC Karcag, RWA Wien, Probstdorfer Saatzucht and Dottenfelderhof for kindly providing the sowings seeds of the wheat varieties. The authors would also thank Pancivis Foundation, the European Union's Horizon 2020 research and innovation programme project LIVESEED (No 727230) and the MNVH (Hungarian National Rural Network) project, No VP-20.2.-162016-00001 for their financial support.

Funding The investigations were financed by the Pancivis Foundation, the European Union's Horizon 2020 research and innovation programme project LIVESEED (No 727230) and the MNVH (Hungarian National Rural Network) project, No VP20.2.-16-2016-00001.

Data availability Data can be made available upon request.

\section{Compliance with ethical standards}

Conflict of interest None.

Ethics approval The submitted work is original and has not been submitted to another journal. The content is not subjected to law.

Consent to participate Not applicable.

Consent for publication All the co-authors have read and approved the manuscript.

Code availability Code can be made available upon request

\section{References}

Avar L (2019) 2019 fuzáriumos év volt, de elég kenyérbúza termett. [2019 Was a year of Fusarium, however, enough bread wheat was harvested]. Magyar Mezőgazdaság on line (in Hungarian) https://magyarmezogazdasag.hu/2019/12/10 /2019-fuzariumos-ev-volt-de-eleg-kenyerbuza-termett 
Bencze S, Puskás K, Vida G, Karsai I, Balla K, Komáromi J, Veisz O (2017) Rising atmospheric CO2 concentration may imply higher risk of Fusarium mycotoxin contamination of wheat grains. Mycotoxin Res. 33:229-236

Brandt K, Leifert C, Sanderson R, Seal CJ (2011) Agroecosystem management and nutritional quality of plant foods: the case of organic fruits and vegetables. Crit. Rev. Plant Sci. 30:177197

Buerstmayr H, Ban T, Anderson JA (2009) QTL mapping and marker-assisted selection for Fusarium head blight resistance in wheat: a review. Plant Breed. 128:1-26

Carr PM, Kandel HJ, Porter PM (2006) Wheat cultivar performance on certified organic fields in Minnesota and North Dakota. Crop Sci. 46:1963-1971

Crespo-Herrera LA, Ortiz R (2015) Plant breeding for organic agriculture: something new? Agric. Food Secur. 4:25. https://doi.org/10.1186/s40066-015-0045-1

Csertán-Halász Á (2020) A magyarországi őszi búza tételek belső Fusarium-fertőzöttség felmérésének eredményei 2019-ben. [Results of the grain Fusarium infection rates of the Hungarian winter wheat items in 2019]. Agrofórum online. https://agroforum.hu/lapszam-cikk/a-magyarorszagi-oszibuza-tetelek-belso-fusarium-fertozottseg-felmeresenekeredmenyei-2019-ben/

Desclaux D, Ceccarelli S, Navazio J, Coley M, Trouche G, Aguirre S, Weltzien E, Lançon J (2012) In: Lammerts van Bueren ET, Myers JR (eds) Organic crop breeding. WileyBlackwell [Royaume-Uni], Chichester, pp 99-123

Dordas C (2008) Role of nutrients in controlling plant diseases in sustainable agriculture. A review. Agron. Sustain. Dev. 28: 33-46. https://doi.org/10.1051/agro:2007051

ENoLL home page. https://enoll.org/about-us/what-are-livinglabs/

European Soil Data Centre (ESDAC) database. https://esdac.jrc. ec.europa.eu/content/soil-map-hungary-clay-mineralassociation-soils-main-substance-regime-type-soils-main

Garson GD (2020) Applications in STATA, IBM SPSS, SAS, R \& HLM. In: Multilevel Modeling. Sage Publications Ltd, Thousand Oaks

Hoaglin DC, Mosteller F, Tukey JW (1991) Fundamentals of exploratory analysis of variance. Wiley, Hoboken

Hox JJ (2010) Techniques and applications. In: Multilevel analysis, Quantitative methodology series, 2nd edn. Routledge, Abington

Hungarian Meteorological Service (2018) Monthly precipitation averages: https://www.met.hu/eghajlat/magyarorszag eghajlata/eghajlati_visszatekinto/elmult_evek_ idojarasa/main.php?no=1\&ful=csapadek

Hungarian Meteorological Service (2019) Monthly precipitation averages: https:/www.met.hu/eghajlat/magyarorszag_ eghajlata/eghajlati_visszatekinto/elmult_evek_ idojarasa/main.php?ful=csapadek

KSH - Hungarian Central Statistical Office (2019) Annual agricultural report. Data in time series, Agriculture. https://www. ksh.hu/stadat_eves_4_1

KSH meteorological database. URL: https://www.ksh. $\mathrm{hu} /$ docs/hun/xstadat/xstadat_eves/i_met001.html

Lammerts van Bueren ET, Hulscher M, Haring M, Jongerden J, van Mansvelt JD, den Nijs APM, Ruivenkamp GTP (1999) Final report: a vision, choices, consequences and steps. In: Sustainable organic plant breeding. Louis Bolk Institut,
Driebergen-Rijsenburg 60p. http://www.louisbolk. org/downloads/1048.pdf

Le Campion A, Oury F, Heumez E et al (2020) Conventional versus organic farming systems: dissecting comparisons to improve cereal organic breeding strategies. Org. Agric. 10: 63-74. https://doi.org/10.1007/s13165-019-00249-3

Lu H, Chang Y, Wu B (2020) The compare organic farm and conventional farm to improve sustainable agriculture, ecosystems, and environment. Org. Agric. https://doi. org/10.1007/s13165-020-00278-3

Mesterházy Á (1977) Reaction of winter wheat varieties to four Fusarium species. Phytopathol 90:104-112

Mesterházy A (1995) Types and components of resistance to Fusarium head blight of wheat. Plant Breed. 114:377-386

Mesterházy Á (2002) Theory and practice of the breeding for Fusarium head blight resistance in wheat. J. Appl. Genet. 43:289-302

Mie A, Andersen HR, Gunnarsson S, Kahl J, Kesse-Guyot E, Rembiałkowska E, Quaglio G, Grandjean P (2017) Human health implications of organic food and organic agriculture: a comprehensive review. Environ. Health 16:111

Mitchell MN (2015) Stata for the behavioral sciences. Stata Press, College Station

Murphy KM, Campbell KG, Lyon SR, Jones SS (2007) Evidence of varietal adaptation to organic farming systems. Field Crop Res. 102:172-177

Murray TD, Parry DW, Cattlin ND (1998) A colour handbook of diseases of small grain cereal crops, vol 142. Manson publishing, London

ÖMKi annual report (2013) Results of the on-farm investigations. https://biokutatas.hu/hu/document/get/138/on-farm-kutatas2013-bra-masodik-ev-eredmenyei

Robson K, Pevalin D (2016) Multilevel modeling in plain language, 1st edn. Sage Publications Ltd, Thousand Oaks

SARE (2012) Bulletins of Sustainable Agriculture Research \& Education https://www.sare.org/LearningCenter/Bulletins/How-to-Conduct-Research-on-Your-Farmor-Ranch/Text-Version/Introduction/What-is-On-FarmResearch

Snoeijers SS, Pérez-García A, Joosten MH et al (2000) The effect of nitrogen on disease develop-ent and gene expression in bacterial and fungal plant pathogens. Eur. J. Plant Pathol. 106:493-506. https://doi.org/10.1023/A:1008720704105

StataCorp (2019) Stata statistical software: release 16. StataCorp LLC, College Station

Stein-Bachinger K, Gottwald F, Haub A, Schmidt E (2020) To what extent does organic farming promote species richness and abundance in temperate climates? A review. Org. Agric. https://doi.org/10.1007/s13165-020-00279-2

Szunics L, Szunics L (1992) Búza kalászfuzárium fertőzési módszerek és a fajták fogékonysága. "Wheat Fusarium head blight inoculation methods and susceptibility of cultivars". Növénytermelés 41:201-210

VICAM DonTest GN-MC9560-1 Rev.B (online) http://www. weber.hu/Downloads/VicamManuals/G1065.pdf

Publisher's note Springer Nature remains neutral with regard to jurisdictional claims in published maps and institutional affiliations. 